\title{
原著論文
}

\section{水田からの炭素ガス年間発生量に及ぼす尿素施用の 影響についての研究事例}

\author{
南川 和則・坂井 直樹・林 久喜 \\ 筑波大学大学院生命環境科学研究科
}

\begin{abstract}
A Case Study on the Effect of Urea Application on the Annual Budget of Carbon Gases Emission from a Paddy Field
\end{abstract}

Kazunori MinamiKawa, Naoki SaKaI, Hisayoshi Hayashi

Graduate School of Life and Environmental Sciences, University of Tsukuba

\section{Introduction}

The carbon gases, methane $\left(\mathrm{CH}_{4}\right)$ and carbon dioxide $\left(\mathrm{CO}_{2}\right)$ are dynamically exchanged between rice paddy fields and the atmosphere. In flooded paddy soils, $\mathrm{CH}_{4}$ is produced by methanogens (methane producing bacteria) under the reductive conditions. Recent studies have estimated the global $\mathrm{CH}_{4}$ emission from paddy fields at $53 \mathrm{Tg}\left(10^{12} \mathrm{~g}\right) \mathrm{CH}_{4} / \mathrm{y}$ (Cao et al., 1998), 25-54 Tg $\mathrm{CH}_{4} / \mathrm{y}$ (Mosier et al., 1998), and 33-49 $\mathrm{Tg} \mathrm{CH}_{4} / \mathrm{y}$ (Neue and Sass, 1998). These account for $4-9 \%$ of the total emission of $598 \mathrm{Tg} \mathrm{CH} \mathrm{CH}_{4} / \mathrm{y}$ (IPCC, 2001), and paddy fields are one of the major sources. On the other hand, the large amount of $\mathrm{CO}_{2}$ is exchanged mainly by the photosynthesis and respiration of rice plants and by soil respiration, compared to the amount of $\mathrm{CH}_{4}$ emission. However, the Global Warming Potential (GWP) of $\mathrm{CH}_{4}$ is reported to be '23' against ' 1 ' of $\mathrm{CO}_{2}$ when considering the 100-year horizon (IPCC, 2001). Of the three major greenhouse gases, $\mathrm{CH}_{4}$, $\mathrm{CO}_{2}$, and nitrous oxide $\left(\mathrm{N}_{2} \mathrm{O}\right)$ emitted from paddy

平成 16 年 12 月 21 日受付

平成 17 年 5 月 7 日受理

Corresponding author

坂井直樹 Naoki SAKAI

テ 305-8572 茨城県つくば市天王台 1-1-1

Ten-nodai 1-1-1, Tsukuba, Ibaraki, 305-8572, Japan

E-mail : nsakai@sakura.cc.tsukuba.ac.jp fields, the contributions to global warming were reported to be 78,16 , and $6 \%$, respectively, with considering the GWPs (Tsuruta et al., 1998). Thus, $\mathrm{CH}_{4}$ and $\mathrm{CO}_{2}$ emissions would affect global warming and also carbon cycle in a paddy field.

The $\mathrm{CH}_{4}$ and $\mathrm{CO}_{2}$ emitted from paddy fields share some substrates such as rice plant residue (straw and root) and soil carbon (soil organic matter). There may be some quantitative relationships between carbon gases emission and the substrates. Although there are some reports on the measurement of the annual $\mathrm{CH}_{4}$ and $\mathrm{CO}_{2}$ emissions from a paddy field (Hayano et al., 1995; Miyata et al., 2000), further studies are necessary to quantify the carbon cycle in a paddy field.

One of the most influential management on $\mathrm{CO}_{2}$ exchange is the change in nitrogen application rate, affecting rice biomass. However, there is no report on the effects of changes in the application rate on the carbon cycle in a paddy field. Nitrogen application is also reported to affect $\mathrm{CH}_{4}$ production and oxidation in the flooded paddy soil with changing the activities of microorganisms. As compared to the effect of ammonium sulfate application on $\mathrm{CH}_{4}$ emission (Schütz et al., 1989; Hori et al., 1990 and 1993; Minamikawa et al., in press), the effect of urea application is under discussion, i.e. conflicting results have been reported. 
The objectives of the study were to measure $\mathrm{CH}_{4}$ and $\mathrm{CO}_{2}$ emission from a paddy field under the conditions of different rates of urea application through a year, and to consider the effects of urea application on global warming and carbon budget in the paddy field without straw incorporation. The $\mathrm{CH}_{4}$ and $\mathrm{CO}_{2}$ fluxes were measured by a closed chamber method. The amount of carbon fixed by rice plants was estimated on the basis of the dry weight and the carbon content. Then the annual budget of carbon gases emission was calculated on the basis of carbon equivalent $\left(\mathrm{g} \mathrm{C} / \mathrm{m}^{2}\right)$ and $\mathrm{CO}_{2}$ equivalent considering the GWPs $\left(\mathrm{g} \mathrm{CO}_{2} / \mathrm{m}^{2}\right)$.

\section{Materials and methods}

\section{1) Experimental site and field management}

The study was carried out at an experimental paddy field of Agricultural and Forestry Research Center (AFRC), University of Tsukuba, Ibaraki, Japan in May of 2002 to April of 2003. The soil in AFRC is classified as Low-Humic Andosol (Haplic Andosol by FAO/Unesco [1990]). This soil is a type of volcanic ash soil with a black surface layer and a rapid percolation rate. The to-

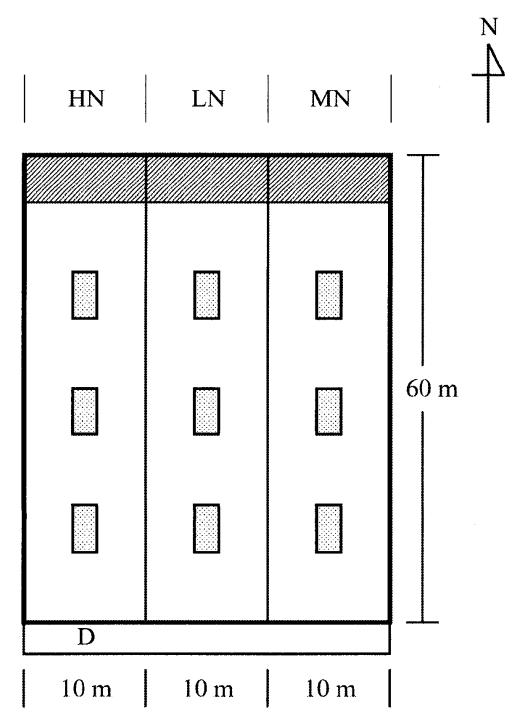

Figure 1. Layout of the experimental paddy field. Gas fluxes are measured in shaded area. Dotted area is a quadrat for measuring rice yields. $\mathrm{D}$ is a ditch for irrigation and drainage. tal carbon and nitrogen contents in the topsoil are 4.57 and $0.328 \%$, respectively.

Three rates of urea application were determined: $120(\mathrm{HN}), 80(\mathrm{MN})$, and $40(\mathrm{LN}) \mathrm{kg} \mathrm{N} / \mathrm{ha}$. The conventional application rate in AFRC is 90 $\mathrm{kg} \mathrm{N} / \mathrm{ha}$. The paddy field was split into three plots of $600 \mathrm{~m}^{2}$ (Figure 1).

In the autumn of 2001, harvested rice straw was removed from the field. Then the field was plowed and fallowed without flooding. In the spring of 2002, urea (at 50\% of the designed application rate) and phosphorous-potassium compound fertilizer $\left(120 \mathrm{~kg} \mathrm{P}_{2} \mathrm{O}_{5} / \mathrm{ha}\right.$ and $90 \mathrm{~kg}$ $\mathrm{K}_{2} \mathrm{O} / \mathrm{ha}$, common to all plots) were broadcasted as a basal dressing on 5 May. The field was then irrigated and puddled. Rice (Oryza sativa L., cultivar: Koshihikari) seedlings were transplant-ed with spacing $30 \mathrm{~cm} \times 15 \mathrm{~cm}\left(22.2 \mathrm{hill} / \mathrm{m}^{2}\right)$ on 14 May. In quadrats investigated, four seedlings were established per hill. Levees were then built on all borders between the plots to prevent runoff of the fertilizers. Urea (at 25\% of the designed application rate) was topdressed twice : on 21 May and 22 July. Agricultural chemicals were applied according to the conventional practice in AFRC. The paddy field was continuously flooded until final drainage on 1 September, except for a few days. Rice was harvested on 20 September. After harvest, rice straw was removed from the field. Then the field was fallowed without flooding until the spring of 2003. Plowing was carried out on 19 December.

2 ) Measurements during the growing period

The $\mathrm{CH}_{4}$ flux was measured by a closed chamber method in duplicate (Yagi et al., 1991). The directions of gas flux and emission were defined as positive for from the soil to the atmosphere and negative for the inverse. The chamber $(60 \mathrm{~cm}$ in length $\times 60 \mathrm{~cm}$ in width $\times 100 \mathrm{~cm}$ in height) covered 8 hills of rice plant at once (Photo 1 ). Measurements of $\mathrm{CH}_{4}$ flux began on 30 May. Gas samples of one liter were taken from the chamber with an air pump (MP-2N ; Sibata Scientific Technology Ltd., Tokyo, Japan) and Tedlar ${ }^{\circledR}$ bags at 0,10 , and 20 minutes after placing the 


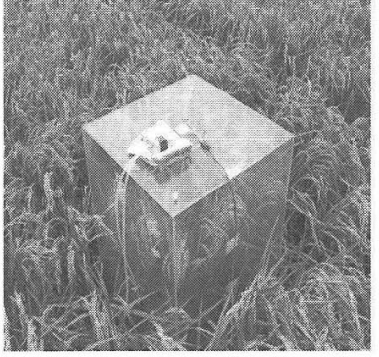

Photo 1. $\mathrm{CH}_{4}$ flux measurement by a closed chamber method during the growing period.

chamber. The $\mathrm{CH}_{4}$ concentrations of the gas samples were analyzed with a gas chromatograph equipped with a flame ionization detector (GC-8 AIF ; Shimadzu Corp., Kyoto, Japan). The $\mathrm{CH}_{4}$ flux ( $\mathrm{mg} \mathrm{CH}_{4} / \mathrm{m}^{2} / \mathrm{h}$ ) was calculated from the following equation.

Gas flux $=\rho \cdot \mathrm{V} / \mathrm{A} \cdot \Delta \mathrm{C} / \Delta \mathrm{t} \cdot 273 / \mathrm{T}$

(Equation 1)

Where $\rho$ is the gas density $\left(\mathrm{mg} / \mathrm{m}^{3}\right), \mathrm{V}$ is the air volume in the chamber $\left(\mathrm{m}^{3}\right)$, A is the cross-sectional area of the chamber $\left(\mathrm{m}^{2}\right), \Delta \mathrm{C} / \Delta \mathrm{t}$ is the average increasing rate of gas concentration in the chamber per unit time ( $\mathrm{ppmv} / \mathrm{h})$, and $\mathrm{T}$ is the average air temperature in the chamber $(\mathrm{K})$. Gas density of $\mathrm{CH}_{4}(\rho \mathrm{CH} 4)$ is $0.716\left(\mathrm{~g} \mathrm{CH}_{4} / \mathrm{m}^{3}\right.$, T $=273 \mathrm{~K})$. The value of $\Delta \mathrm{C} / \Delta \mathrm{t}$ was determined from the linear regression between the $\mathrm{CH}_{4}$ concentrations and the passed time. The $\mathrm{CH}_{4}$ flux was measured once a week (11:00-14:00 h) until harvest. After the final drainage, the flux was additionally measurcd scveral times to detect the $\mathrm{CH}_{4}$ flush that is the direct diffusion from the soil to the atmosphere.

Soil redox potentials (Eh) at a depth of $5 \mathrm{~cm}$ were monitored with a portable Eh meter (EHS120 ; Fujiwara Scientific Company Co., Ltd, Tokyo, Japan) and platinum-tipped electrodes inserted in the soil, in triplicate on each measured day of $\mathrm{CH}_{4}$ flux after 20 June. Soil Eh before 20 June were not monitored because the electrodes were in trouble. Air temperature at a height of 1 $\mathrm{m}$ and soil temperatures at a depth of $5 \mathrm{~cm}$ were monitored at 30-minute intervals during the growing period with data loggers (TR-52 ; T\&D Co., Nagano, Japan).

Rice grain (rough rice) and straw yields of the 60-hill quadrate were investigated in triplicate.

3 ) Measurements during the fallow period

At one month after harvest, measurement of $\mathrm{CO}_{2}$ flux began in duplicate, and continued once a week or every other week $(11: 00-14: 00 \mathrm{~h})$ until 17 April 2003. The sampling method and chamber were the same as the growing period. Gas samples were taken at 0,10 , and 20 minutes after the chamber placement on a water-filled concave frame set on the soil surface. The $\mathrm{CO}_{2}$ concentrations of the gas samples were analyzed with a gas chromatograph equipped with a thermal conductivity detector (GC-8AIT ; Shimazdu Corp., Kyoto, Japan). The chamber covered 8 ratoons of rice plant before the plowing. Air temperature at a height of $1 \mathrm{~m}$ ( $\mathrm{T}_{\text {out }}$ ) and soil temperatures at a depth of $5 \mathrm{~cm}$ were monitored at 30-minute intervals during the fallow period. The $\mathrm{CO}_{2}$ flux was calculated from Equation $1(\rho \mathrm{co} 2=1.977 \mathrm{~g}$ $\left.\mathrm{CO}_{2} / \mathrm{m}^{3}\right)$.

4 ) Calculation of the total $\mathrm{CH}_{4}$ and $\mathrm{CO}_{2}$ emissions

During the growing period, the total $\mathrm{CH}_{4}$ emission was calculated by plotting $\mathrm{CH}_{4}$ fluxes against the days. The $\mathrm{CH}_{4}$ flux during the fallow period was disregarded because of no flooding. On the basis of the definition of GWPs (IPCC, 2001), the total $\mathrm{CH}_{4}$ emission converted to $\mathrm{CO}_{2}$ equivalent $\left(\mathrm{g} \mathrm{CO}_{2} / \mathrm{m}^{2}\right)$ was calculated with multiplying the $\mathrm{CH}_{4}$ emission $\left(\mathrm{g} \mathrm{CH}_{4} / \mathrm{m}^{2}\right)$ by 23 .

During the fallow period, the total $\mathrm{CO}_{2}$ emission was attributed to two parts, soil respiration and fixation by rice ratoons. Both parts were separately considered. For estimating soil respiration, the regression line between the average $\mathrm{CO}_{2}$ flux of all plots $\left(\mathrm{mg} \mathrm{CO}_{2} / \mathrm{m}^{2} / \mathrm{h}\right)$ and the average air temperature in the chamber of all plots $\left(\mathrm{T}_{\mathrm{in}},{ }^{\circ} \mathrm{C}\right.$ ) was analyzed on the basis of the parameters after the plowing.

$\mathrm{CO}_{2}$ flux $=\mathrm{a} \mathrm{T}_{\text {in }}+\mathrm{b} \quad$ (Equation 2) 
Table 1. Rice grain and straw yields from all plots and the carbon and nitrogen fixations $(n=3)$

\begin{tabular}{ccccccc}
\hline \multirow{2}{*}{ Plot } & \multicolumn{2}{c}{ Rice yield $\left({\left.\mathrm{g} \mathrm{DW} / \mathrm{m}^{2}\right)}^{2}\right.$} & \multicolumn{2}{c}{ Carbon fixation $\left(\mathrm{g} \mathrm{C} / \mathrm{m}^{2}\right)$} & \multicolumn{2}{c}{ Nitrogen fixation $\left(\mathrm{g} \mathrm{N} / \mathrm{m}^{2}\right)$} \\
\cline { 2 - 7 } & Grain ${ }^{1)}$ & Straw & Grain ${ }^{1)}$ & Straw & Grain $^{1)}$ & Straw \\
\hline HN & $670 \mathrm{a}$ & $746 \mathrm{a}$ & $287 \mathrm{a}$ & $292 \mathrm{a}$ & $8.38 \mathrm{a}$ & $3.49 \mathrm{a}$ \\
$\mathrm{MN}$ & $595 \mathrm{~b}$ & $639 \mathrm{~b}$ & $255 \mathrm{~b}$ & $252 \mathrm{~b}$ & $7.17 \mathrm{~b}$ & $3.11 \mathrm{~b}$ \\
LN & $484 \mathrm{c}$ & $532 \mathrm{c}$ & $207 \mathrm{c}$ & $209 \mathrm{c}$ & $5.17 \mathrm{c}$ & $2.15 \mathrm{c}$ \\
\multirow{2}{*}{ ANOVA } & $* *$ & $* * *$ & $* *$ & $* * *$ & $* * *$ & $* * *$ \\
\hline
\end{tabular}

${ }^{1)}$ Grain indicates rough rice.

${ }^{* *}$ and ${ }^{* * *}$ represent significant difference by ANOVA at $\mathrm{p}=0.01$ and 0.001 , respectively.

The same letters within each column are not significantly different at $\mathrm{p}=0.05$ by Tukey's HSD test.

Where $\mathrm{a}$ and $\mathrm{b}$ are coefficients.

Equation 2 was also applied to the period before the plowing. Then the regressed $\mathrm{CO}_{2}$ flux was calculated by substituting $\mathrm{T}_{\text {out }}$ for $\mathrm{T}_{\text {in. }}$. The $\mathrm{CO}_{2}$ emission due to soil respiration was calculated by plotting the regressed $\mathrm{CO}_{2}$ fluxes against the time. The $\mathrm{CO}_{2}$ fixation by the ratoons was subtracted from the $\mathrm{CO}_{2}$ emission due to soil respiration, and the total $\mathrm{CO}_{2}$ emission during the fallow period was calculated.

\section{5 ) Carbon contents in the soil and rice plants}

The topsoil $(5-10 \mathrm{~cm})$ was sampled in triplicate, six times during the growing period and three times during the fallow period. The soil samples were air-dried and screened through a 1mm mesh sieve. Soil carbon (total carbon) content was analyzed by a dry-combustion method with a C-N analyzer (NC-800 : Sumika Chemical Analysis Service, Osaka, Japan).

The harvested rice grain and straw were partly oven-dried and weighed in triplicate. The dried grain and straw samples were separately milled through a $0.25-\mathrm{mm}$ sieve, and the carbon and nitrogen contents were analyzed by the method mentioned above. The ratio of carbon fixed in belowground to carbon fixed in aboveground was estimated at 0.25 on the basis of other data in Japan (Hoshikawa, 1975 ; Hayano, 1995; Koizumi, 2001). The total carbon content in the whole rice plants was calculated from the dry weight, the carbon content, and the ratio.

\section{Results and discussion}

1) Rice yield and carbon fixation

Table 1 shows the grain and straw yields from all plots, and the carbon and nitrogen fixations. The yields and the carbon and nitrogen fixations increased with increases in urea application rate. Although the nitrogen contents increased with increases in urea application rate, the carbon contents were not affected (data not shown).

The amounts of carbon fixed by the whole rice plants in $\mathrm{HN}, \mathrm{MN}$, and LN plots were estimated at 724,634 , and $520 \mathrm{~g} \mathrm{C} / \mathrm{m}^{2}$, respectively. The carbon fixed in grain, straw, and root increased with increases in urea application rate.

2 ) $\mathrm{CH}_{4}$ emission during the growing period

There were no differences in soil temperature at a depth of $5 \mathrm{~cm}$ between plots during the growing period, and the diurnal average temperature of the soil ranged between 15.2 and $30.9^{\circ} \mathrm{C}$. The activities of methanogens and methanotrophs (methane oxidizing bacteria) may not have been affected by the soil temperature.

Figure 2 shows the changes in soil Eh for all plots during the growing period. Although soil Eh in all plots before 20 June were not monitored, the changing patterns were similar through the growing period. Soil Eh in all plots reached - $150 \mathrm{mV}$ after the middle of July, and decreased to near $-200 \mathrm{mV}$. After the final drainage, Soil Eh in all plots rapidly increased to higher than $0 \mathrm{mV}$. However, rainfalls returned them to 


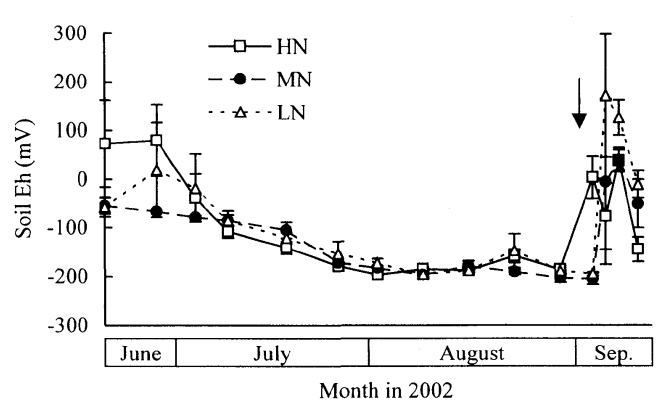

Figure 2. Changes in soil Eh for all plots during the growing period. Arrow indicates the final drainage on 1 September. Vertical bars indicate the standard error $(n=3)$.

lower than $0 \mathrm{mV}$ again. Under different rates of ammonium sulfate application in AFRC, the decrease in soil Eh was delayed with increase in the application rate (Minamikawa et al., in press). As compared with ammonium sulfate application, effect of urea application on the changes in soil Eh was small, may little affecting $\mathrm{CH}_{4}$ flux.

Figure 3 shows the changes in $\mathrm{CH}_{4}$ flux for all plots during the growing period. In all plots, $\mathrm{CH}_{4}$ fluxes were lower than $1 \mathrm{mg} \mathrm{CH} / 4 \mathrm{~m}^{2} / \mathrm{h}$ when soil Eh was higher than- $150 \mathrm{mV}$. After soil Eh decreased to lower than- $150 \mathrm{mV}, \mathrm{CH}_{4}$ fluxes began to increase. After the final drainage, the $\mathrm{CH}_{4}$ flushes were detected in all plots. The total $\mathrm{CH}_{4}$ emissions from $\mathrm{HN}, \mathrm{MN}$, and $\mathrm{LN}$ plot were 28.4, 44.1, and $54.2 \mathrm{~g} \mathrm{CH}_{4} / \mathrm{m}^{2}$, respectively. The $\mathrm{CH}_{4}$ emission decreased with increases in urea application rate.

This result was consistent with Cai et al. (1997), Klüber and Conrad (1998), and Bodelier et al. (2000). On the other hand, contrary results, i.e. $\mathrm{CH}_{4}$ emission increased with increases in urea application rate, were attributed to increases in soil pH by urea hydrolysis (Wang et al., 1992), increases in rice biomass (Banik et al., 1996), and the inhibition of methanotrophs by ammonium (Conrad and Rothfuss, 1991 ; Kumaraswamy et al., 1997 ; Dubey, 2003). However, these explanations could not apply to the result of the present study.

Among various explanations for the decreased

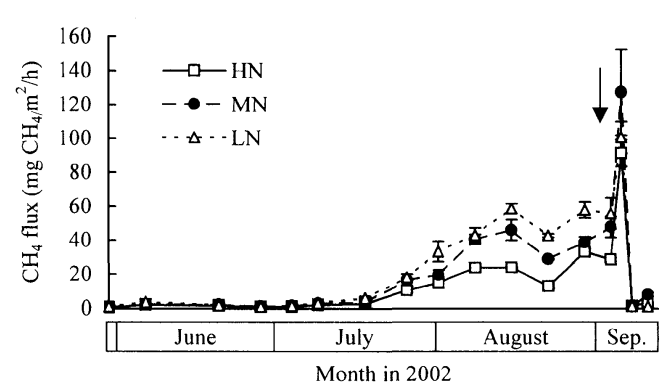

Figure 3. Changes in $\mathrm{CH}_{4}$ flux for all plots during the growing period. Arrow indicates the final drainage on 1 September. Vertical bars indicate the standard error $(n=2)$.

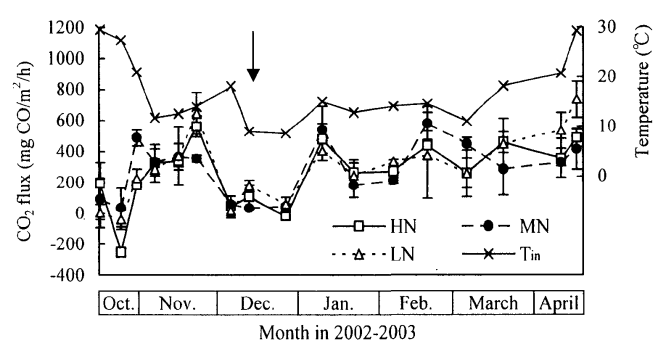

Figure 4. Changes in $\mathrm{CO}_{2}$ flux for all plots (left yaxis) and the average air temperature in the chamber of all plots $\left(\mathrm{T}_{\mathrm{in}}\right.$, right $\mathrm{y}$ axis) during the fallow period. Arrow indicates the plowing on 19 December. Vertical bars for $\mathrm{CO}_{2}$ flux indicate the standard error $(n=2)$.

$\mathrm{CH}_{4}$ emission at higher rates of urea application, increases in activities of methanotrophs under a high concentration of ammonium (Bodelier et al., 2000) may be a reasonable explanation for the present study. They reported that the nitrogen limitation of methanotrophs would restrict the $\mathrm{CH}_{4}$ oxidation under the conditions of the microcosms.

3) $\mathrm{CO}_{2}$ emission during the fallow period

Figure 4 shows the changes in $\mathrm{CO}_{2}$ flux for all plots and the average air temperature in the chamber of all plots $\left(\mathrm{T}_{\text {in }}\right)$ during the fallow period. Although incorporated rice roots were different between plots (Table 2), there were no differences in $\mathrm{CO}_{2}$ flux possibly because the absolute amounts of the incorporated root in all 
plots were too small. Moreover, lower soil temperatures (the average during the fallow period was $6.8^{\circ} \mathrm{C}$ ) may have delayed the decomposition of the incorporated root.

Factors determining $\mathrm{CO}_{2}$ flux were different between before and after the plowing. When rice ratoons were actively growing (17-31 October), photosynthesis of the ratoons strongly affected $\mathrm{CO}_{2}$ flux. Thus, $\mathrm{CO}_{2}$ flux was decreased with increase in Tin during this period. Soil consolidation and thus high content of moisture lowered $\mathrm{CO}^{2}$ flux as a result of a low porosity. When the ratoons were dying (7 November-13 December), $\mathrm{CO}_{2}$ flux increased with increases in the soil temperature. However, $\mathrm{CO}_{2}$ flux was still lowered by the soil consolidation. Koizumi et al. (1994) reported that the carbon fixed by rice ratoons during the fallow period was $36.1 \mathrm{~g} \mathrm{C} / \mathrm{m}^{2}$, and this value was cited for the present study.

After the plowing, the following equation was obtained from Equation 2.

$$
\mathrm{CO}_{2} \text { flux }=21.8 \cdot \mathrm{T}_{\text {in }}+9.24
$$

The coefficient of determination $\left(\mathrm{R}^{2}\right)$ was 0.649 . Lack of sampling frequency and spatial variation between field points affected the low $\mathrm{R}^{2}$.

The $\mathrm{CO}_{2}$ emissions due to soil respiration before and after the plowing were estimated at 548 and $355 \mathrm{~g} \mathrm{CO}_{2} / \mathrm{m}^{2}$, respectively, from the above equation. Thus, the total $\mathrm{CO}_{2}$ emission during the fallow period (soil respiration - fixation by the ratoons, $132 \mathrm{~g} \mathrm{CO}_{2} / \mathrm{m}^{2}$ ) was $771 \mathrm{~g} \mathrm{CO}_{2} / \mathrm{m}^{2}$ (Table 3 ).

Nakadai et al. (1996) reported the exponential correlation between diurnal soil respiration (SR, g $\mathrm{CO}_{2} / \mathrm{m}^{2} / \mathrm{d}$ ) and diurnal average temperature of the soil at a depth of $5 \mathrm{~cm}$ (Tsoil, ${ }^{\circ} \mathrm{C}$ ) in an upland field with the Humic Andosol : $\mathrm{SR}=0.948$. $\exp \left(0.126 \cdot \mathrm{T}_{\text {soil }}\right), \mathrm{R}^{2}=0.981$. The result of substituting the soil temperatures monitored in the present study to Nakadai's equation was $748 \mathrm{~g}$ $\mathrm{CO}_{2} / \mathrm{m}^{2}$. Koizumi (2001) reported that the heterotrophic respiration in a paddy field during the fallow period was $484 \mathrm{~g} \mathrm{CO}_{2} / \mathrm{m}^{2}$ on the basis of three-year measurements. Tsuruta et al. (1997) reported the lower $\mathrm{CO}_{2}$ flux in the paddy field than those in uplands of the temperate region during the fallow period. In the present study, $39 \%$ of the total days during the fallow period had more than 1-mm precipitation per day. The effect of rainfalls on $\mathrm{CO}_{2}$ flux was disregarded when calculating the total emission, resulting in the overestimation. The regression line calculated from the parameters after the plowing (Equation 2) was also applied to before. The $\mathrm{CO}_{2}$ emission due to soil respiration before the plowing may have been also overestimated because the soil consolidation was disregarded. With considering these negative effects, true value of the total $\mathrm{CO}_{2}$ emission was thought to be lower than the calculated one.

\section{4) Soil carbon content}

Figure 5 shows the changes in soil carbon content for all plots through the year. The carbon contents ranged between $4.41-4.66 \%$. With considering the ranges of statistical standard error, half of the seasonal changes were thought to be inherent variations in the field. The average carbon contents in $\mathrm{HN}, \mathrm{MN}$, and $\mathrm{LN}$ plot were 4.51, 4.51 , and $4.56 \%$, respectively. Although soil carbon content was decreased with increase in application rate of ammonium sulfate during the growing period in AFRC (Minamikawa et al., in press), no differences were found between plots in the present study. Generally, soil carbon content in Andosol is higher, and moreover, which is

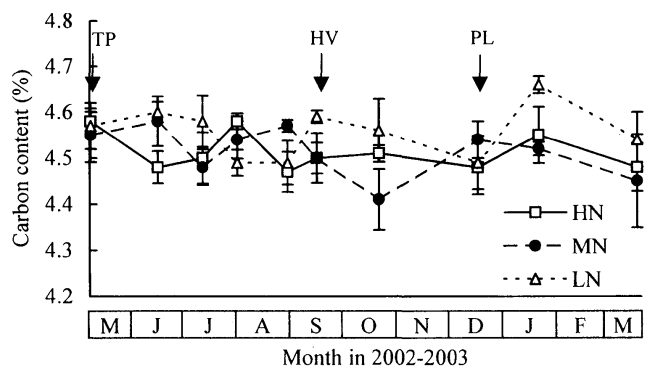

Figure 5. Changes in soil carbon content for all plots throughout the year. Arrows indicate the following farm practices: TP for transplanting on 14 May, HV for harvest on 20 September, and PL for plowing on 19 December. Vertical bars indicate the standard error $(n=3)$. 
Table 2. Annual budget of carbon-gases emission from all plots converted to carbon equivalent $\left(\mathrm{g} \mathrm{C} / \mathrm{m}^{2}\right)$

\begin{tabular}{|c|c|c|c|c|c|c|c|c|}
\hline \multirow{2}{*}{ Plot } & \multirow{2}{*}{$\mathrm{CH}_{4}$} & \multicolumn{3}{|c|}{$\mathrm{CO}_{2}$ Growing ${ }^{1)}$} & \multirow{2}{*}{$\begin{array}{l}\mathrm{CO}_{2} \\
\text { Fallow }\end{array}$} & \multirow{2}{*}{$\begin{array}{c}\mathrm{CO}_{2} \\
\text { Sub total }\end{array}$} & \multirow{2}{*}{$\begin{array}{l}\text { Total } \\
\text { exchange }\end{array}$} & \multirow{2}{*}{$\begin{array}{l}\text { Total emission } \\
\text { from the soil }\end{array}$} \\
\hline & & Grain & Straw & Root & & & & \\
\hline & A & B & $\mathrm{C}$ & $\mathrm{D}$ & $\mathrm{E}$ & F & G & $\mathrm{H}$ \\
\hline HN & 21.3 & -287 & -292 & -145 & 210 & -514 & -493 & 87 \\
\hline MN & 33.1 & -255 & -252 & -127 & 210 & -425 & -392 & 116 \\
\hline $\mathrm{LN}$ & 40.7 & -207 & -209 & -104 & 210 & -310 & -270 & 147 \\
\hline
\end{tabular}

1) The values calculated from the carbon fixed by rice plants.

$G=A+F=A+B+C+D+E$

$\mathrm{H}=\mathrm{A}+\mathrm{D}+\mathrm{E}$

Table 3. Annual budget of carbon-gases emission from all plots converted to $\mathrm{CO}_{2}$ equivalent $\left(\mathrm{g} \mathrm{CO}_{2} / \mathrm{m}^{2}\right)$

\begin{tabular}{|c|c|c|c|c|c|c|c|c|}
\hline \multirow{2}{*}{ Plot } & \multirow{2}{*}{$\mathrm{CH}_{4}{ }^{17}$} & \multicolumn{3}{|c|}{$\mathrm{CO}_{2}$ Growing ${ }^{2)}$} & \multirow{2}{*}{$\begin{array}{c}\mathrm{CO}_{2} \\
\text { Fallow }\end{array}$} & \multirow{2}{*}{$\begin{array}{c}\mathrm{CO}_{2} \\
\text { Sub total }\end{array}$} & \multirow{2}{*}{$\begin{array}{l}\text { Total } \\
\text { exchange }\end{array}$} & \multirow{2}{*}{$\begin{array}{l}\text { Total emission } \\
\text { from the soil }\end{array}$} \\
\hline & & Grain & Straw & Root & & & & \\
\hline & A & B & $\mathrm{C}$ & D & $\mathrm{E}$ & $\mathrm{F}$ & G & $\mathrm{H}$ \\
\hline $\mathrm{HN}$ & 653 & -1054 & -1070 & -531 & 771 & -1884 & -1231 & 893 \\
\hline $\mathrm{MN}$ & 1014 & -936 & -925 & -465 & 771 & -1555 & -541 & 1320 \\
\hline LN & 1247 & -760 & -767 & -382 & 771 & -1138 & 109 & 1636 \\
\hline
\end{tabular}

1) The values converted to 23-time $\mathrm{CO}_{2}$ emission with considering the GWP of $\mathrm{CH}_{4}$ for the 100-year horizon (IPCC, 2001).

2) The values calculated from the carbon fixed by rice plants.

$\mathrm{G}=\mathrm{A}+\mathrm{F}=\mathrm{A}+\mathrm{B}+\mathrm{C}+\mathrm{D}+\mathrm{E}$

$\mathrm{H}=\mathrm{A}+\mathrm{D}+\mathrm{E}$

largely occupied by humic substance. Thus, soil carbon content in Andosol is thought to be constant through a year. As well as the total $\mathrm{CO}_{2}$ emission during the fallow period, the small amounts of incorporated root in all plots may have not caused the difference in soil carbon content.

5 ) Annual budget of carbon gases emission

Table 2 shows the annual budget of carbon gases emission from all plots as expressed by carbon equivalent. The total carbon-gas exchange and emission were mostly determined by $\mathrm{CO}_{2}$ through the year. The total carbon-gas exchanges were negative in all plots. The absolute amounts of exchanged gases increased with increases in urea application rate, i.e. increases in fixation by rice plants. However, the carbon fixed by rice aboveground was removed from the field. The total carbon-gas emissions from the soil were 87-147 $\mathrm{g} \mathrm{C} / \mathrm{m}^{2}$, and decreased with in- creases in urea application rate.

Koizumi (2001) reported that the annual carbon budget in a paddy soil was $20 \mathrm{~g} \mathrm{C} / \mathrm{m}^{2} \mathrm{com}$ pared to $270-320 \mathrm{~g} \mathrm{C} / \mathrm{m}^{2}$ in an upland singlecropping field. Miyata et al. (2003) estimated the annual carbon budget in a paddy field under the conditions of rice straw incorporation at 150-190 $\mathrm{g} \mathrm{C} / \mathrm{m}^{2}$ mainly by a micrometeorological method. Thus, 87-147 $\mathrm{g} \mathrm{C} / \mathrm{m}^{2}$ of the present study was well estimated.

Table 3 shows the annual budget of carbon gases emission from all plots as expressed by $\mathrm{CO}_{2}$ equivalent. The total $\mathrm{CO}_{2}$-equivalent exchanges in all plots widely ranged between positive to negative as a result of large contribution of $\mathrm{CH}_{4}$ emission with considering the GWPs. The total $\mathrm{CO}_{2}$-equivalent emission from the soil decreased with increases in urea application rate. The $\mathrm{CH}_{4}$ emissions from all plots accounted for $73-77 \%$ of the total $\mathrm{CO}_{2}$-equivalent emission from 
the soil, which are comparable to the estimation by Tsuruta et al. (1998).

In addition, for considering the total effect on global warming, it is necessary to include $\mathrm{N}_{2} \mathrm{O}$ emission. The $\mathrm{N}_{2} \mathrm{O}$ emission is reported to increase with increase in application rate of nitrogen fertilizer (Hua et al., 1997 ; Tsuruta, 2000). Thus, excessive urea application is not thought to be desirable for mitigating greenhouse gases emission.

Consequently, increases in urea application rate were effective for single-year mitigations both of carbon gases emission and carbon loss from the soil. However, the total carbon-gas emissions from the soil were positive in all plots. Thus, successive rice cultivation without organic matter application is thought to gradually decrease soil carbon storage. To solve this problem, it is necessary to apply organic matter for maintaining or increasing soil carbon storage : especially rice straw is appropriate from the viewpoint of the carbon cycle in a paddy field. This also involves carbon sequestration in the soil. However, organic matter application inevitably causes large emissions of $\mathrm{CH}_{4}$ and $\mathrm{CO}_{2}$. Decreasing one emission has the possibility of increasing the other emission because they share common substrates. Thus, low $\mathrm{CO}_{2}$-equivalent emission and large storage of soil carbon would be an ideal state for the carbon cycle in a paddy field from the both viewpoints. Further studies are necessary to balance between carbon gases emission and soil carbon storage.

\section{References}

Banik, A., M. Sen and S. P. Sen (1996) : Effects of inorganic fertilizers and micronutrients on methane production from wetland rice (Oryza sativa L.). Biol. Fertil. Soils 21;319-322.

Bodelier, P. L. E., A. P. Hahn, I. R. Arth and P. Frenzel (2000) : Effects of ammonium-based fertilization on microbial processes involved in methane emission from soils planted with rice. Biogeochem. 51 ; 225-257.

Cai, Z., G. Xing, X. Yan, H. Xu, H. Tsuruta, K. Yagi and K. Minami (1997) : Methane and nitrous oxide emission from rice paddy fields as affected by nitrogen fertilizers and water management. Plant Soil $196 ; 7-14$.

Cao, M., K. Gregson and S. Marshall (1998): Global methane emission form wetlands and its sensitivity to climate change. Atmos. Env. $32 ; 3293-3299$.

Conrad, R. and F. Rothfuss (1991): Methane oxidation in the soil surface layer of a flooded rice field and the effect of ammonium. Biol. Fertil. Soils $12 ; 28-32$.

Dubey, S. K. (2003) : Spatio-kinetic variation of methane oxidizing bacteria in paddy soil at mid-tillering : Effect of N-fertilizers. Nutr. Cycling Agroecosyst. 65 ; 53-59.

FAO/Unesco (1990) : Soil Map of the World ; Revised Legend. World Soil Resources Report 60. FAO, Rome.

Hayano, K. (1995) : Quantitative analysis of carbon cycle system in agro-ecosystems. In : National Institute for Agro-Environmental Sciences (NIAES, Ed). Study on the carbon dioxide and carbon cycle related to the global warming: Global environmental research fund. NIAES, Tsukuba, pp. 43-50 (in Japanese with English abstract).

Hori, K., K. Inubushi, S. Matsumoto and H. Wada (1990) : Competition for acetic acid between methane formation and sulfate reduction in the paddy soil. Jpn. J. Soil Sci. Plant Nutr. 61; 572-578 (in Japanese with English abstract).

Hori, K., K. Inubushi, S. Matsumoto and H. Wada (1993) : Competition for hydrogen between methane formation and sulfate reduction in a paddy soil. Jpn. J. Soil Sci. Plant Nutr. 64;363367 (in Japanese with English abstract).

Hoshikawa, K. (1975) : The growing rice plant: an anatomical monograph. Nobunkyo, Tokyo, pp. 209 (in Japanese).

Hua, X., X. Guangxi, Z. Cai and H. Tsuruta (1997): Nitrous oxide emissions from three rice paddy fields in China. Nutr. Cycling Agroecosyst. $49 ; 23-28$.

IPCC (2001) : Climate change 2001: The scientific 
basis. Cambridge University Press, Cambridge.

Klüber, H. and R. Conrad (1998) : Effects of nitrate, nitrite, $\mathrm{NO}$ and $\mathrm{N}_{2} \mathrm{O}$ on methanogenesis and other redox processes in anoxic rice field soil. FEMS Microbial. Ecol. 25 ; 301-318.

Koizumi, H., T. Nakadai, Y. Bekku and M. Satoh (1994) : Carbon dynamics and budgets in two different cropping agro-ecosystems in Japan. INTECOL $6 ; 88$.

Koizumi, H. (2001) :Chapter 10. Carbon cycling in croplands. In : Shiyomi, M. and H. Koizumi (Eds.). Structure and function in agroecosystem design and management. CRC Press, Boca Raton, pp. 207-226.

Kumaraswamy, S., B. Ramakrishnan, S. N. Satpathy, A. K. Rath, S. Misra, V. R. Rao and N. Sethunathan (1997) :Spatial distribution of methane-oxidizing activity in a flooded rice soil. Plant Soil $191 ; 241-248$.

Minamikawa, K., N. Sakai and H. Hayashi (in press): The effect of ammonium sulfate application on methane emission and soil carbon content of a paddy field in Japan. Agric. Ecosyst. Environ.

Miyata, A., H. Nagai, T. Yamada, M. Saito, Y. Harazono, Md.A. Baten and C. Takamura (2003) : Carbon budget of a single cropping paddy field in central Japan. Proceedings of the International Workshop on Flux Observation and Research. 1-3 Dec. 2003, Beijing, 129-130.

Mosier, A. R., J. M. Duxbury, J. R. Freney, O. Heinemeyer, K. Minami and D. E. Johnson (1998) : Mitigating agricultural emissions of methane. Climatic Change $40 ; 39-80$.

Nakadai, T., H. Koizumi, Y. Bekku and T. Totsuka (1996) : Carbon dioxide evolution of an upland rice and barley, double cropping field in central Japan. Ecol. Res. 11 ; 217-227.

Neue, H. U. and R. L. Sass (1998) : The budget of methane from rice fields. IGACtivities Newsletter $12 ; 3-11$.

Schütz, H., A. Holzapfel-Pschorn, R. Conrad, H. Rennenberg and W. Seiler (1989) : A 3-year continuous record on the influence of daytime, season and fertilizer treatment on methane emission rates from an Italian rice paddy. J. Geophys. Res. 94 ; 16405-16416.

Tsuruta, H. (2000) : Interaction between greenhouse gases and soil ecosystem. 3. The emission of nitrous oxide from nitrogenous compounds produced by human activity. Jpn. J. Soil Sci. Plant Nutr. $71 ; 554-564$ (in Japanese).

Tsuruta, H., K. Kanda and T. Hirose (1997) : Nitrous oxide emission from a rice paddy field in Japan. Nutr. Cycling Agroecosyst. 49; 51-58.

Tsuruta, H., Y. Ozaki, Y. Nakajima and H. Akiyama (1998) : Methodology for LCA in agricultural systems - Impact assessment of rice paddy fields on atmospheric and aquatic environments - Proceedings on the Third International Conference on EcoBalance ; 209-212.

Wang, Z., R. D. Delaune, C. W. Lindau and W. H. Patrick Jr. (1992) : Methane production from anaerobic soil amended with rice straw and nitrogen fertilizers. Fert. Res. 33 ; 115-121.

Yagi, K., H. Tsuruta and K. Minami (1991) : Manual of $\mathrm{CH}_{4}$ and $\mathrm{N}_{2} \mathrm{O}$ flux measuring. Collected papers on environmental planning/ Division of Environmental Assessment, National Institute for Agro-Environmental Sciences 7 ; 143-158 (in Japanese).

\section{Abstract}

The $\mathrm{CH}_{4}$ and $\mathrm{CO}_{2}$ emissions from the paddy field without straw incorporation were measured through a year to consider their effects on global warming and carbon cycle in a paddy field. Three rates of urea application were determined to examine the effect of changes in rice biomass on the carbon budget: 120,80 , and $40 \mathrm{~kg} \mathrm{~N} / \mathrm{ha}$. During the growing period, $\mathrm{CH}_{4}$ flux of the flooded field was measured by a closed chamber method. The amount of carbon fixed by rice plants was estimated on the basis of the dry weight and the carbon content. During the fallow period, $\mathrm{CO}_{2}$ flux was measured by the chamber 
method.

With increases in urea application rate, $\mathrm{CH}_{4}$ emission decreased and the carbon fixed by rice plants increased. The $\mathrm{CO}_{2}$ fluxes at all rates of urea application changed similarly because the absolute amounts of incorporated rice root were small. The $\mathrm{CH}_{4}$ contributed to the total $\mathrm{CO}_{2}$ equivalent emission from the soil by $73-77 \%$ with considering the GWPs. The carbon-gas emission from the soil was mostly determined by $\mathrm{CO}_{2}$ through the year, and was estimated at 87-147 $\mathrm{g}$ $\mathrm{C} / \mathrm{m}^{2}$.

Consequently, increases in urea application rate were effective for a single-year mitigation both of carbon gases emission and carbon gases loss from the soil. However, the carbon gases loss appeared to be positive at all rates of urea application. This result indicates a necessity of organic matter application to sustain soil carbon storage. The overall consideration is necessary to balance greenhouse gases emission with soil carbon storage.

\section{Keywords}

methane, carbon dioxide, rice, paddy field, global warming, carbon cycle, urea

\section{摘要}

本研究は, 水田からのメタンおよび二酸化炭素 (炭素ガス) 年間発生量の定量と, その温室効果ガ
スとしての地球温暖化への影響そして水田内炭素 循環に及ぼす影響の検討を目的とした，実験では， イネのバイオマス変化をもたらす尿素施用量を要 因として，3水準を設定した. 密閉チャンバー法 により，水稲生育期のメタンフラックス抢よび休 閑期の二酸化炭素フラックスを測定した。また， イネによる炭素固定量を乾物重と炭素含有率から 算出した。これらを基に, 年間炭素ガス発生量を, 炭素換算と温暖化ポテンシャルを考慮した二酸化 炭素換算で算出した。

尿素施用量の増加に伴い, メ夕ン発生量は減少 し，イネによる炭素固定量は増加した。二酸化炭 素フラックスの推移には尿素施用量の影響は見ら れなかったが，これはイネ根すき込みの絶対量が 少なかったことが原因と考えられた。二酸化炭素 換算の年間炭素ガス発生量に対し, メタンはその $73 \sim 77 \%$ を占めた。炭素換算の年間炭素ガス発 生量は主に二酸化炭素により決定され，87～147 $\mathrm{g} \mathrm{C} / \mathrm{m}^{2}$ の土壤面からの放出と見積もられた.

以上の結果から, 水田における尿素施用量の増 加は炭素由来の温室効果ガス発生量の抑制と, 土 壤からのガス由来の炭素ロスの抑制にとって効果 的であることが明らかにされた，しかし，土壤面 炭素収支はすべての施用水準でロスとなったこと から, 有機物施用の必要性が改めて示唆された。

$$
\text { キーワード }
$$

メタン, 二酸化炭素, イネ, 水田, 地球温暖化, 炭素 循環, 尿素 